Short Communication http://ajol.info/index.php/ijbcs http://indexmedicus.afro.who.int

\title{
Grain iron density variability among new farmer-preferred experimental millet varieties from Niger
}

\author{
Goudia Daoura BACHIR ${ }^{1 *}$, Issa KARIMOU ${ }^{2}$ and C. Tom HASH ${ }^{1}$ \\ ${ }^{I}$ International Crops Research Institute for the Semi-Arid Tropics (ICRISAT), Dryland Cereals Research Program, ICRISAT \\ Sahelian Center, BP 12404, Niamey, Niger \\ ${ }^{2}$ Institute National de la Recherche Agronomique du Niger (INRAN), CERRA, Maradi, Niger \\ ${ }^{*}$ Corresponding author; E-mail: bachirgaoh@gmail.com
}

\section{ACKNOWLEDGMENTS}

This work has been undertaken as part of the CGIAR Research Program on Dryland Cereals. Financial support of the McKnight Foundation is gratefully acknowledged (ICRISAT grants no. 06-14 and 10134). Thanks are also due to all technicians at the ICRISAT Sadoré millet breeding unit for their support in field work.

\begin{abstract}
Grain micronutrient content assessment is important in breeding pearl millet, in order to maintain or improve its high nutritional quality. Grain samples of 12 farmer-preferred pearl millet varieties produced in four representative environments in Niger during the 2013 rainy season were assessed for $\mathrm{Fe}, \mathrm{Zn}, \mathrm{Al}$ and $\mathrm{P}$ grain densities using energy dispersive X-ray fluorescence spectroscopy. Combined analysis of variance revealed significant $(\mathrm{P}<0.01)$ variation among entries across environments only for Fe grain density, which had a broad-sense heritability of $89 \%$. Fe grain density varied from 30.4 to $39.2 \mathrm{mg} \mathrm{kg}^{-1}$ among these varieties, with a mean of $32.4 \mathrm{mg} \mathrm{kg}^{-1}$. Among the 12 varieties, ICRI-Tabi and ICMV-IS 13131 (reselected ICRI-Tabi) showed the highest Fe grain densities.

(C) 2016 International Formulae Group. All rights reserved.
\end{abstract}

Keywords: Genetic variability, Grain iron, heritability, malnutrition, micronutrients, pearl millet.

\section{INTRODUCTION}

Micronutrient malnutrition, particularly zinc $(\mathrm{Zn})$ and iron $(\mathrm{Fe})$ deficiencies, afflicts over three billion people worldwide due to low dietary intake. In some Sahelian African countries, millets, and particularly pearl millet (Pennisetum glaucum (L.) R. Br.), can represent more than $75 \%$ of total cereal production (FAO, 2004) and thus represent an important proportion of total dietary intake for millions of people in this region.

Several reports indicate the existence of large variability for grain $\mathrm{Fe}$ and $\mathrm{Zn}$ concentrations in pearl millet. For example, a recent study by Pucher et al. (2014) of 72 pearl millet accessions from West and Central Africa (WCA) assessed in Niger showed moderate ranges in mineral density (24.2 to $48.7 \mathrm{mg} \mathrm{kg}^{-1}$ for Fe and 19.8 to $43.4 \mathrm{mg} \mathrm{kg}^{-1}$ 
for $\mathrm{Zn})$. A study focusing on the grain mineral density of 225 Sudanese pearl millet accessions evaluated in Sudan also found wide variation for $\mathrm{Fe}$ and $\mathrm{Zn}$ ranging from 19.7 to $86.4 \mathrm{mg} \mathrm{kg}^{-1}$ for $\mathrm{Fe}$ and 13.5 to 82.4 $\mathrm{mg} \mathrm{kg}{ }^{-1}$ for $\mathrm{Zn}$ (Bashir et al., 2014). Rai et al. (2013) revealed two-fold variation for $\mathrm{Fe}$ density ( 31 to $61 \mathrm{mg} \mathrm{kg}^{-1}$ ) and Zn density (32 to $54 \mathrm{mg} \mathrm{kg}^{-1}$ ) among 122 commercial and pipeline hybrids of pearl millet developed in India.

Development of pearl millet varieties with high grain density and/or availability of $\mathrm{Fe}$ and/or $\mathrm{Zn}$ could contribute to the reduction of $\mathrm{Fe}$ and $\mathrm{Zn}$ deficiencies in millet-dependent populations in WCA (Hama et al., 2012; Pucher et al., 2014). Therefore, the objective of this study was to assess the genetic variability of $\mathrm{Fe}, \mathrm{Zn}, \mathrm{Al}$ and $\mathrm{P}$ grain concentrations among 12 pearl millet farmerpreferred varieties tested across representative sites in Niger.

\section{MATERIALS AND METHODS}

Field experiments were conducted during the 2013 rainy season at four sites in Niger (ISC-Sadoré Low-P, ISC-Sadoré Moderate-P, INRAN-Maradi and INRANTara). The experimental materials consisted of 12 pearl millet entries open-pollinated varieties, including four pairs of experimental varieties undergoing farmer-participatory varietal improvement as well as appropriate local landrace and improved variety controls. These were arranged in randomized complete block designs with three replications per site. Plot size was 28 hills, arranged as four rows of 7 hills each, with $75 \mathrm{~cm}$ between rows and $80 \mathrm{~cm}$ between hills within rows. At ISCSadoré, two sets of the trial were conducted in a low-fertility field having Bray-1 P below 6 $\mathrm{mg} \mathrm{P} \mathrm{kg}{ }^{-1}$ soil. The low-P treatment at ISCSadoré received $18 \mathrm{~kg} \mathrm{~N} \mathrm{ha}^{-1}$ as basal fertilizer in the form of urea, while the moderate-P treatment there received $14 \mathrm{~kg} \mathrm{~N} \mathrm{ha}^{-1}, 14 \mathrm{~kg}$ $\mathrm{P}_{2} \mathrm{O}_{5} \mathrm{ha}^{-1}$ and $14 \mathrm{~kg} \mathrm{~K}_{2} \mathrm{O} \mathrm{ha}^{-1}$ in the form of NPK at the time of sowing. INRAN-Tara received $30 \mathrm{~kg} \mathrm{~N}^{-1}, 30 \mathrm{~kg} \mathrm{P}_{2} \mathrm{O}_{5} \mathrm{ha}^{-1}$ and 30 $\mathrm{kg} \mathrm{K} \mathrm{K}_{2} \mathrm{O} \mathrm{ha}^{-1}$ in the form of NPK as basal fertilizer, and $18 \mathrm{~kg} \mathrm{~N} \mathrm{ha}^{-1}$ and $46 \mathrm{~kg} \mathrm{P}_{2} \mathrm{O}_{5} \mathrm{ha}^{-1}$ in the form of DAP were applied at sowing at INRAN-Maradi. At Maradi and Sadoré, the crops were subsequently side-dressed with urea in several splits, as and when rainfall permitted.

Open-pollinated grain samples were collected manually at maturity, directly from the panicles into paper envelopes to avoid grain sample contamination by soil or metal equipment. Grain samples were analyzed nondestructively for $\mathrm{Fe}, \mathrm{Zn}, \mathrm{Al}$ and $\mathrm{P}$ density at ICRISAT-Sadoré using energy dispersive $\mathrm{X}$ ray fluorescence spectroscopy (EDXRF) with an Oxford Instrument X- Supreme 8000 (Jenkins, 1999). Statistical analysis was performed using SAS 8.1 software.

\section{RESULTS AND DISCUSSION}

The combined analysis of variance across environments (Table 1) showed significant environment effects on grain mineral concentration for all the studied micronutrients ( $\mathrm{Fe}, \mathrm{Zn}, \mathrm{Al}$ and $\mathrm{P}$ ), but showed no significant genotype $\times$ environment interaction. The genotype mean square was significant only for $\mathrm{Fe}$, indicating the presence of significant variation among entries for grain Fe concentration. The extent of variation in the $\mathrm{Fe}, \mathrm{Zn}$ and $\mathrm{Al}$ concentrations observed is presented in Table 2. The observed low levels of Al grain density indicated that the grain samples were essentially free from soil contamination. Grain $\mathrm{Fe}$ density ranged from 30.4 to $39.2 \mathrm{mg} \mathrm{kg}^{-1}$ with a mean of $32.4 \mathrm{mg}$ $\mathrm{kg}^{-1}$ and grain $\mathrm{Zn}$ density from 32.8 to 38.7 $\mathrm{mg} \mathrm{kg}{ }^{-1}$ with a mean of $35.4 \mathrm{mg} \mathrm{kg}^{-1}$. These ranges were substantially narrower than those recently reported for pearl millet (Hama et al., 2012; Rai et al., 2013; Bashir et al., 2014; Pucher et al., 2014), perhaps because the tested materials did not include any Iniari landrace-derivatives. Based on their mean performances across the four environments, the varieties ICRI-Tabi and ICMV-IS 13131 (reselected ICRI-Tabi) were identified as stable and more promising for grain $\mathrm{Fe}$ 
density. These two varieties have very compact panicles that confer some degree of resistance to millet head miner (Heliocheilus albipunctella), which in the Sahel can cause severe grain yield losses on early-flowering pearl millet varieties having less compact panicles, including most Iniari derivatives.

Broad-sense heritabilities were estimated across environments for $\mathrm{Fe}, \mathrm{Zn}, \mathrm{Al}$ and $\mathrm{P}$ grain densities. Highest heritabilities were recorded for grain $\mathrm{Fe}(89 \%)$ and $\mathrm{Zn}$ (49\%), while that for grain $\mathrm{Al}$ was low (9\%) and grain $\mathrm{P}$ was not heritable. The high heritability value for grain $\mathrm{Fe}$ content indicates it was less influenced by environment. High heritability estimates for grain $\mathrm{Fe}$ in pearl millet were previously reported by Bashir et al. (2014) and Govindaraj et al. (2011).

Table 1: Mean squares for studied micronutrients of the 12 pearl millet entries as obtained from combined ANOVA of the four environments (ISC-Sadoré Low- and Moderate-P, INRAN-Maradi and INRAN-Tara).

\begin{tabular}{|c|c|c|c|c|c|}
\hline Source of variation & DF & $\mathbf{F e}$ & $\mathbf{Z n}$ & Al & $\overline{\mathbf{P}}$ \\
\hline Environment (E) & 3 & $95.78^{*}$ & $419.6^{* 2}$ & $293.67^{* * *}$ & $9546.58^{* * *}$ \\
\hline Genotype (G) & 11 & $100.59^{* *}$ & $37.86^{\mathrm{ns}}$ & $14.48^{\mathrm{ns}}$ & $1704.05^{\mathrm{ns}}$ \\
\hline $\mathrm{G} \times \mathrm{E}$ & 33 & $8.00^{\mathrm{ns}}$ & $14.97^{\mathrm{ns}}$ & $12.79^{\mathrm{ns}}$ & $2344.89^{\mathrm{ns}}$ \\
\hline Error & 88 & 11.08 & 23.67 & 17.93 & 2146.83 \\
\hline
\end{tabular}

Table 2: Combined means, standard errors, coefficients of variation and broad-sense heritabilities of $\mathrm{Fe}, \mathrm{Zn}$ and $\mathrm{Al}$ grain densities $\left(\mathrm{mgkg}^{-1}\right)$ for the 12 pearl millet varieties evaluated at ISC-Sadoré Low- and Moderate-P, INRAN-Maradi and INRAN-Tara during the 2013 rainy season.

\begin{tabular}{lccc}
\hline Entry name & $\mathbf{F e}\left(\mathbf{m g k g}^{-\mathbf{1}}\right)$ & $\mathbf{Z n}\left(\mathbf{m g k g}^{-1}\right)$ & $\mathbf{A l}\left(\mathbf{m g k g}^{-\mathbf{1}}\right)$ \\
\hline ICRI-Tabi & $39.2 \mathrm{a}$ & $38.7 \mathrm{a}$ & $14.9 \mathrm{~b}$ \\
ICMV-IS 13131(reselected ICRI-Tabi) & $37.2 \mathrm{a}$ & $37.7 \mathrm{ab}$ & $14.7 \mathrm{~b}$ \\
Tera PPBV C0 & $30.9 \mathrm{c}$ & $37.6 \mathrm{ab}$ & $14.1 \mathrm{~b}$ \\
Tera PPBV C1 & $30.4 \mathrm{c}$ & $34.6 \mathrm{bc}$ & $13.8 \mathrm{~b}$ \\
Falwel PPBV C0 & $31.2 \mathrm{c}$ & $35.2 \mathrm{bc}$ & $14.8 \mathrm{~b}$ \\
Falwel PPBV C1 & $31.0 \mathrm{c}$ & $35.5 \mathrm{bc}$ & $15.9 \mathrm{ab}$ \\
Serkin Haoussa PPBV C0 & $31.0 \mathrm{c}$ & $34.6 \mathrm{bc}$ & $15.9 \mathrm{ab}$ \\
Serkin Haoussa PPBV C1 & $30.6 \mathrm{c}$ & $32.8 \mathrm{c}$ & $15.0 \mathrm{~b}$ \\
Local check 1 & $31.5 \mathrm{bc}$ & $33.2 \mathrm{c}$ & $18.0 \mathrm{a}$ \\
Local check 2 & $31.2 \mathrm{c}$ & $34.9 \mathrm{bc}$ & $15.2 \mathrm{ab}$ \\
Improved check 1: SOSAT-C88 & $33.8 \mathrm{~b}$ & $35.4 \mathrm{bc}$ & $15.4 \mathrm{ab}$ \\
Improved check 2: ICMV-IS 89305 & $30.5 \mathrm{c}$ & $34.9 \mathrm{bc}$ & $14.5 \mathrm{~b}$ \\
Mean & 32.4 & 35.4 & 15.2 \\
Minimum & 30.4 & 32.8 & 13.8 \\
Maximum & 39.2 & 38.7 & 18.0 \\
CV $(\%)$ & 10 & 14 & 28 \\
SE $( \pm)$ & 0.96 & 1.4 & 1.2 \\
$\mathrm{~h}^{2}(\%)$ & 89 & 49 & 9 \\
lsd $(P=0.05)$ & 2.3 & 3.2 & 3.0 \\
\hline
\end{tabular}

Means not sharing a common letter in a column differ significantly at $0.05 \%$ level of probability 


\section{Conclusion}

The estimated high broad-sense heritability for grain $\mathrm{Fe}$ density (Table 2) indicates there is scope for genetic improvement of $\mathrm{Fe}$ concentration in pearl millet through selection.

The varieties ICRI-Tabi and ICMV-IS 13131 (reselected ICRI-Tabi) can be recommended to farmers in Niger for consumption to improve their nutrition.

\section{COMPETING INTERESTS}

The authors declare that they have no competing interests.

\section{AUTHORS' CONTRIBUTIONS}

CTH conceived and designed the experiments; GDB and IK performed the experiments; GDB analyzed the data and drafted the paper. All authors read and approved the manuscript.

\section{ACKNOWLEDGMENTS}

Thanks are due to all technicians at the ICRISAT Sadoré millet breeding unit for their support in field work.

\section{REFERENCES}

Bashir EM, Ali AM, Ali AM, Melchinger AE, Parzies HK, Haussmann BIG. 2014. Characterization of Sudanese pearl millet germplasm for agro-morphological traits and grain nutritional values. Plant Genetic Resources, 12(1):35-47. DOI: http:dx.doi.org/10.1017/S147926211300 0233

FAO. 2004. Agricultural data: FAOSTAT; http://faostat.fao.org/faostat/default.jsp.
Govindaraj M, Selvi B, Rajarathinam S, Sumathi P. 2011. Genetic variability and heritability of grain yield components and grain mineral concentration in India's pearl millet (Pennisetum glaucum (L.) R. Br.) accessions. African Journal of Food, Agriculture, Nutrition and Development, 11(3):4758-4771. DOI: http://dx.doi.org/10.4314/ajfand.v11i3.6 6627.

Hama F, Icard-Vernière C, Guyot J-P, Rochette I, Diawara B, Mouquet-Rivier C. 2012. Potential of non-GMO biofortified pearl millet (Pennisetum glaucum) for increasing iron and zinc content and their estimatedbioavailability during abrasive decortication. International Journal of Food Science, 47(8):1660-1668. DOI: $10.1111 / \mathrm{j} .1365-$ 2621.2012.03017.x

Jenkins R. 1999. X-Ray Fluorescence Spectrometry (2nd edn). John Wiley \& Sons, Inc.: New York, p. 5-12, 75-76.

Pucher A, Høgh-Jensen H, Gondah J, Hash CT, Haussmann BIG. 2014. Micronutrient density and stability in West African pearl millet: Potential for biofortification. Crop Science, 54(4): 1709-1720. DOI:10.2135/cropsci2013.11.0744

Rai KN, Yadav OP, Rajpurohit BS, Patil HT, Govindaraj M, Khairwal IS, Rao AS, Shivade H, Pawar VY, Kulkarni MP. 2013. Breeding pearl millet cultivars for high iron density with zinc density as an associated trait. Journal of SAT Agricultural Research, 11: 1-7. http://oar.icrisat.org/id/eprint/7291 